\title{
Seasonal Variations in the Histometric Characteristics of the Reproductive Organs of Pubertal West African Dwarf Bucks in their Native Tropical Environment
}

\author{
Variaciones Estacionales en las Características Morfométricas de los Órganos Reproductivos de la \\ Cabra Enana Púber Macho del Oeste Africano en su Medio Ambiente Nativo Tropical
}

"Bitto, I. I.; **Egbunike, G. N. \& ${ }^{* * *}$ Akusu, M. O.

BITTO, I. I.; EGBUNIKE, G. N. \& AKUSU, M. O. Seasonal variations in the histometric characteristics of the reproductive organs of pubertal West African dwarf bucks in their native tropical environment. Int. J. Morphol., 26(2):397-401, 2008.

SUMMARY: As ambient temperature and humidity are high all year round within clearly defined dry and rainy seasons in our humid tropical environment, we evaluated the effects of season on the histometric characteristics of the reproductive organs of pubertal West African dwarf bucks using 8 healthy animals. There were no significant differences $(\mathrm{p}>0.05)$ between the rainy and dry seasons in the basement membrane of the testes, seminiferous tubular diameter, and round spermatid nuclear diameter. There were also similarities ( $>0.05$ ) between the seasons in epididymal luminal diameters, epididymal epithelial heights as well as in Leydig/sertoli cell ratio and sertoli cell index. Quadratic regression analyses showed that all the histometric characteristics of the testes are highly predictable from the live weights of the animals. It is concluded from these results that the WAD goat would not have a restricted breeding season in it native tropical environment. Young sires could therefore be selected early in life for planned improvement programmes in research institutions and breeding centers thus providing farmers with quicker returns for their investments.

KEY WORDS: Goats; Testes; Histometric; Seasons; Tropics; Farmers.

\section{INTRODUCTION}

Goats along with sheep have been reported to have the widest ecological distribution of any domestic livestock (Salem et al., 1982) and seem to be better adapted to hot environments than both sheep and cattle (Coop, 1982; ValezNauer et al., 1982). Bianca \& Kunz (1978) reported that goats were more susceptible to heat stress than sheep and cattle as measured by a rise in body temperature outward signs of stress and reduction in performance. Other workers also confirmed increases in body temperature in goats with increasing environmental temperature (Hetzel et al., 1988; Egbunike \& Bitto, 1980).

High ambient temperatures however have for long been known to depress spermatogenesis, and hot climates tend to negate the effects of the descent of the testes into the scrotum (Egbunike et al.,1985). Moreover, a primary response of most species to heat stress is a reduction in energy intake (Bongso et al., 1982) with a concomitant lowered productivity. With ambient temperature high all year round in the humid tropics and with significant differences between seasons in the physiologically effective temperature (PET) for goats in the environment (Egbunike \& Bitto), it becomes necessary to investigate the effects of season on all aspects of the physiology of reproduction in tropical breeds of goats in their native environment. Such information will be useful in the applications of modern reproductive biotechnological techniques like artificial insemination (AI) and intracytoplasmic sperm injection (ICSI) in the tropics to augment the productivity of goats.

Due to the flexible integration of the WAD goat into the most diverse socio-economic conditions in the West African sub-region (Sumberg \& Cassaday, 1985), its improvement not only in terms of meat production but also milk production as has been done in France (Leboeuf et al., 1998), will be of immense benefits to farmers in the sub-region.

\footnotetext{
* Department of Animal Breeding and Physiology, University of Agriculture Makurdi, Makurdi, Nigeria.

** Animal Physiology Laboratory, Department of Animal Science, University of Ibadan, Ibadan, Nigeria.

${ }^{* * *}$ Department of Veterinary Reproduction and Surgery, University of Ibadan, Ibadan, Nigeria.
} 
Though season in our recent report (Bitto \& Egbunike, 2006) had no effect on sperm production, the efficiency of spermatogenesis and the sperm storage capacity of pubertal WAD bucks in the same environment, there still remains a dearth of information on the effect of season on the histometric characteristics of the reproductive organs in these animals as they are constantly exposed to the prevalent ambient temperatures in the seasons as they scavenge. This situation becomes the more worrisome as whole body heating of animals is known to interfere with spermatocyte as well as spermatid maturation (Vandenmark \& Free, 1970) and effects focal necrosis in the seminiferous tubules (Sod-Moriah et al., 1974). We thus undertook to provide information on the effect of season on the histometric characteristics of the reproductive organs of pubertal WAD bucks in their native humid tropical environment.

\section{MATERIAL AND METHOD}

Location and Climate. The study took place at the Teaching and Research Farm of the University of Ibadan, Nigeria. Ibadan is located at latitude $07^{\circ} 201 \mathrm{~N}$ and longitude $03^{\circ}$ $501 \mathrm{E}$, with a hot humid equatorial climate divided into four three monthly seasons namely: The early rainy season (April - June), the late rainy season (July - September), the early dry season (October - December) and the late dry season (January - March) (Egbunike \& Steinbach, 1979). The seasons in this study were limited to only two - the early rainy season (April - June) and the early dry season (October - December).

Animals and Management. Eigth healthy kid bucks, 4 in each season were randomly selected for the study. They were all weaned between 35 and 40 days of age and were housed in a standard goat barn with concrete floor and adequate protection from prevalent ambient temperature and other climatic conditions. They were fed a maize - based concentrate ration supplemented with forage ad libitum and also supplied with salt lick and cool clean drinking water always.

Puberty. The preputial smear technique described by Vandenberg (1971) in male golden hamsters and Egbunike (1979) in boars was applied to the animals to determine the onset of puberty. The cotton buds used in the present study were the bel de luxe - Hartmann Ltd, brand. The bucks in the rainy season attained puberty at an age of $153.95 \pm 4.08$ days and weighed between 8.86 and $11.00 \mathrm{~kg}$ while these in the dry season attained puberty at $154.62 \pm 5.04$ days and weighed between 8.40 and $11.97 \mathrm{~kg}$.
Histological preparations. Mid parenchymal portions of left and right organs were fixed in more than 20 times their volume of aqueous Bouin's fixative for $24 \mathrm{~h}$. The samples were there after dehydrated in increasing concentrations of ethyl alcohol and cleared in two changes of chloroform, before they were embedded in molten paraffin wax. Histological sections of $7 \mu$ thick were obtained using a microtome and stained with haematozylin-eosin for histometric evaluations.

Histometry. Histometric evaluations were done at $800 \mathrm{x}$ magnification using a Zeiss microscope after the eye piece had been dully calibrated with a stage micrometer.

Statistical analyses. Data were subjected to the student ' $t$ ' test for a comparism of seasonal means, while quadratic regression analyses were used in the prediction of the histometric characteristics of the reproductive organs from body weight (Steel \& Torrie, 1980).

\section{RESULTS AND DISCUSSION}

Though there were numerical differences between seasons in the histometric characteristics of the reproductive organs of these animals, season had no significant effect $(p>0.05)$ on any parameter (Table I). Seminiferous tubular diameters and their mean in the present study were however higher than values reported for Saanen x Local and Jumnapari $\mathrm{x}$ Local bucks in the same age group (Bongso et al.) else where. This superiority of WAD bucks over their counterparts elsewhere in this regard may be an indication of a higher sperm production potential and a higher sperm storage capacity in the WAD breed as earlier reported (Bitto \& Egbunike).

The stability of seminiferous tubular diameters, round spermatid nuclear diameters, epididymal luminal diameters and epithelial heights, as well as Leydig /Sertoli cell ratio and Sertoli cell index within the year, obtained in the present study is in agreement with the non effect of season on circulating testosterone level earlier reported in the breed by Bitto et al. (2000). These reports thus imply that inspite of the seasonal differences in ambient temperature in the tropics, the WAD buck would not have a restricted breeding season. Thimonier et al. (1986) actually considered high ambient temperature as a secondary factor affecting reproductive capacity in small ruminants. Roca et al. (1992) also did not find the magnitude of seasonal effects on the semen of Murciano-Granadian goats in the Mediterranean area sufficient to prevent bucks from being used for breeding through out the year. With photoperiodicity fairly static in tropical regions (Willis, 2001), the reproductive capacity of these animals in their native environment is therefore unlikely to change with season. 
Table I. Seasonal variations in the histometric characteristics of the reproductive organs of the pubertal WAD buck.

\begin{tabular}{|c|c|c|c|}
\hline Parameter/season & Early rainy season & Early dry season & Mean \\
\hline Basement of membrane testes $(\mu)$ & $5.79 \pm 0.04$ & $5.64 \pm 0.05$ & $5.72 \pm 0.056$ \\
\hline Seminiferous tubular diameter $(\mu)$ & $140.46+2.68$ & $132.33+3.18$ & $136.40+2.87$ \\
\hline Round spermatid nucle ar diame ter $(\mu)$ & $4.25+0.06$ & $4.14+0.01$ & $4.20+0.04$ \\
\hline \multirow[t]{3}{*}{ Epididymal luminal diameters $(\mu)$} & caput $16.38 \pm 0.05$ & $15.98 \pm 0.05$ & $16.18 \pm 0.14$ \\
\hline & corpus $13.41+0.06$ & $12.7 \overline{6}+0.03$ & $13.09+0.23$ \\
\hline & cauda $27.47 \pm 0.90$ & $23.92 \pm 0.95$ & $25.69 \pm 1.25$ \\
\hline \multirow[t]{3}{*}{ Epididymal epithelial heights $(\mu)$} & caput $4.61 \pm 0.02$ & $4.52 \pm 0.02$ & $4.57 \pm 0.03$ \\
\hline & corpus $5.40+0.02$ & $5.27+0.06$ & $5.34+0.04$ \\
\hline & cauda $3.67 \pm 0.03$ & $3.59 \pm 0.02$ & $3.63 \pm 0.02$ \\
\hline Leydig/Sertoli cell cell ratio & $0.41 \overline{ \pm} 0.04$ & $0.51 \pm 0.09$ & $0.46 \pm 0.03$ \\
\hline Sertoli cell index & $11.26+1.47$ & $16.69+3.04$ & $13.98 \overline{+1} .91$ \\
\hline
\end{tabular}

$($ means + sem $) *$ sem $=$ Standard error of mean $*=(p>0.05)$.

Table II. Prediction equations for testicular and epididymal histometric characteristics from body weight based on quadratic regression analysis.

\begin{tabular}{lccc}
\hline Dependent variable (Y) & \multicolumn{1}{c}{$\begin{array}{c}\text { Regression equations } \\
\mathbf{X}=\text { Body weight }\end{array}$} & $\mathbf{r}$ & $\mathbf{R}^{2}$ \\
\hline Mean seminiferous tubular diameter & $\mathrm{Y}=83.38+19.09 \mathrm{x}-1.19 \mathrm{x} \mathrm{x}^{2}$ & $0.85^{* * * *}$ & $0.72^{* * * *}$ \\
Caput epididymal luminal diameter & $\mathrm{Y}=15.21+0.39 \mathrm{x}-.002 \mathrm{x}^{2}$ & $0.51^{* *}$ & $0.37^{*}$ \\
Corpus epididymal luminal diameter & $\mathrm{Y}=11.93+0.37 \mathrm{x}-0.01 \mathrm{x}^{2}$ & $0.66^{* *}$ & $0.45^{*}$ \\
Cauda epididymal luminal diameter & $\mathrm{Y}=19.14+0.79 \mathrm{x}+0.30 \mathrm{x}^{2}$ & $0.78^{* * *}$ & $0.60^{* *}$ \\
Basement membrane of testes & $\mathrm{Y}=5.35+0.12 \mathrm{x}-0.00 \mathrm{x}^{2}$ & $0.57^{* *}$ & $0.32^{*}$ \\
Epithelial height of caput epididymis & $\mathrm{Y}=4.69-0.09 \mathrm{x}-0.02 \mathrm{x}^{2}$ & $0.62^{* *}$ & $0.38^{*}$ \\
Epithelial height of corpus epididymis & $\mathrm{Y}=503+0.05 \mathrm{x}+0.01 \mathrm{x}^{2}$ & $0.72^{* * *}$ & $0.51^{* * *}$ \\
Epithelial height of cauda epididymis & $\mathrm{Y}=3.50+0.04 \mathrm{x}+0.00 \mathrm{x}^{2}$ & $0.55^{* *}$ & $0.30^{*}$ \\
\hline
\end{tabular}

$*=(\mathrm{p}<0.05), * *=(\mathrm{p}<0.01), * * *=(\mathrm{p}<0.001)$.

Table III. Prediction equations for testicular epididymal histometric characteristics from testicular weight based on quadratic regression analysis.

\begin{tabular}{lccc}
\hline Dependent variable (Y) & $\begin{array}{c}\text { Regression equations } \\
\mathbf{X}=\text { Paired testes weight }\end{array}$ & $\mathbf{r}$ & $\mathbf{R}^{2}$ \\
\hline Mean seminiferous tubular diameter & $\mathrm{Y}=110.05+1.17 \mathrm{x}-0.01 \mathrm{x}^{2}$ & $0.88^{* * *}$ & $0.77^{* * *}$ \\
Caput epididymal luminal diameter & $\mathrm{Y}=15.51+0.03 \mathrm{x}-0.00 \mathrm{x}^{2}$ & $0.75^{* * * *}$ & $0.56^{* * *}$ \\
Corpus epididymal luminal diameter & $\mathrm{Y}=12.07+0.05 \mathrm{x}-0.00 \mathrm{x}^{2}$ & $0.79^{* * *}$ & $0.62^{* * *}$ \\
Cauda epididymal luminal diameter & $\mathrm{Y}=17.98+0.32 \mathrm{x}-0.00 \mathrm{x}^{2}$ & $0.87^{* * *}$ & $0.75^{* * *}$ \\
Basement membrane of testes & $\mathrm{Y}=5.44+0.01 \mathrm{x}-0.00 \mathrm{x}^{2}$ & $0.65^{* *}$ & $0.42^{* *}$ \\
Epithelial height of caput epididymis & $\mathrm{Y}=4.49+0.00 \mathrm{x}+8.93 \mathrm{x}^{2}$ & $0.76^{* * *}$ & $0.57^{* *}$ \\
Epithelial height of corpus epididymis & $\mathrm{Y}=5.11+0.01 \mathrm{x}-0.00 \mathrm{x}^{2}$ & $0.79^{* * *}$ & $0.62^{* * *}$ \\
Epithelial height of cauda epididymis & $\mathrm{Y}=3.49+0.01 \mathrm{x}-0.00 \mathrm{x}^{2}$ & $0.71^{* * * *}$ & $0.50^{* *}$ \\
\hline
\end{tabular}

$* *=(\mathrm{p}<0.01), * * *=(\mathrm{p}<0.001)$.

The regression model showed (Tables II and III) that the histometric characteristics of the reproductive organs of these animals are predictable from changes in body weight and may thus enhance the early selection of good sires, based on body weight and testicular measurements.

The results of this work imply that the WAD buck would not require a restricted breeding season in its native environment.
The predictability of the histometric characteristics of the reproductive organs from body weight in this breed lends ground for the early selection of good sires based on the prediction of sperm production rates as testicular measurements are related to sperm production. Goat farmers could thus have quicker payoffs by selling young bucks to research institutions and government owned breeding centers for planned breeding programmers all year round. 
BITTO, I. I.; EGBUNIKE, G. N. \& AKUSU, M. O. Variaciones estacionales en las características morfométricas de los órganos reproductivos de la cabra enana púber macho del Oeste Africano en su medio ambiente nativo tropical. Int. J. Morphol., 26(2):397-401, 2008.

RESUMEN: Como la temperatura ambiental y la humedad son altas durante todo el año dentro de estaciones secas y lluviosas claramente definidas en nuestro ambiente húmedo tropical, se evaluaron los efectos de las estaciones en la características histométricas de los órganos reproductivos de cabras enanas machos púber del África Occidental, usando 8 animales sanos. No hubo diferencias significativas $(p>0,05)$ entre las estaciones de lluvia y secas, en la membrana basal de los testículos, diámetro de los túbulos seminíferos, y el diámetro de la envoltura nuclear espermática. Sin embargo, hubo similitudes ( $p>0,05)$ entre las diferentes estaciones en el diámetro luminal del epidídimo, altura del epitelio del epidídimo, así como en la proporción de células Leydig/Sertoli e índice de células de Sertoli. El análisis de regresión cuadrática mostró que todas las características histométricas de los testículos son altamente predecibles desde el peso de los animales vivos. Se concluye de estos resultados, que las cabras enanas del África Occidental no tendrían una restricción estacional para tener crías en el ambiente tropical nativo. Padres jóvenes por lo tanto, podrían ser seleccionados tempranamente en la vida para programas de mejora planeados en instituciones de investigación y centros criadores los que provean a granjeros de rápidos retornos por sus inversiones.

PALABRAS CLAVE: Caprinos; Testículos; Histométrico; Estaciones; Trópico; Granjeros.

\section{REFERENCES}

Bianca, W. \& Kunz, P. Physiological reactions of three breeds of goats to cold, heat and high altitude. Livest. Prod. Sci., 5:57-69, 1978.

Bitto, I. I.; Akusu, M. O.; Egbunike, G. N. \& Akpokodje, J. U. A comparative study of spermatozoal abnormalities and some biochemical characteristics of Ovine and Caprine semen in the humid tropics. Trop. J. Anim. Sci., 3(1):169-74, 2000.

Bitto, I. I. \& Egbunike, G. N. Seasonal variations in sperm production, gonadal and extragonadal sperm reserves in pubertal West African Dwarf Bucks in their native tropical environment. Livest. Res. Rural Dev.18(9), Article \#134, 2006. Retrieved November 26, 2006, from http://www.cipav.org.co/1rrd/1rrd18/9/ bitt18134.htm

Bongso, T. A.; Jainudeen, M. R. \& Siti Zahrah, A. Relationship of scrotal circumference to age, body weight and onset of spermatogenesis in goats. Theriogenology, 18(5):513-24, 1982.

Coop, I. Sheep and Goat Production. New York, Elsevier, 1982.

Egbunike, G. N. Development of puberty in Large White boars in a humid tropical environment. Acta Anat. (Basel), 104(4):400-5, 1979.

Egbunike, G. N. \& Bitto, I. I. Effects of season on the Physiological responses of the West African Dwarf buck to acute exposure to tropical sunlight. Trop. Anim. Prod. Invest., 2:20-7, 1980.

Egbunike, G. N. \& Steinbach, J. Season of variations in the sperm production rates of boars in a humid tropical environment. Niger. J. Agric. Sci., 1:21-6, 1979.

Egbunike, G. N.; Togun, V. A. \& Agiang, E. A. Sperm production in ruminants in hot humid climates. World Review of Animal Production, 21(3):11-7, 1985.

Hetzel, D. J. S.; Bennett, I. L.; Holmes, C. R.; Encarnacae, R. O. \& Mackinnon, M. J. Description and evaluation of a telemetry system for measuring body temperature in cattle. J. Agric. Sci. Comb., 110(2): 233-8, 1988.

Leboeuf, B.; Manfredi, E.; Boue, P.; Piacere, A.; Brice, G.; Baril, G.; Broqua, C.; Humblot, P. \& Terqui, M. Artificial insemination of dairy goats in France. Livestock Prod. Sci., 55(3):193-203, 1998.

Roca, J.; Martinez, E.; Vazquez, J. M.; Ruiz, S. \& Coy, P. Characteristics and seasonal variations in the semen of Murciano-Granadina goats in the Mediterranean area. Anim. Reprod. Sci., 29:255-62, 1992.

Salem, M. H.; Yousef, M. K.; El-Sherbing, A. A. \& Khalil, M. H. Physiologiy of Sheep and Goats in the tropics. In: Animal Production in the Tropics. M K Yousef editor, New York, Praeger Publishers CBs Educational and Professional Publishing, 1982. pp.123-47. 
BITTO, I. I.; EGBUNIKE, G. N. \& AKUSU, M. O. Seasonal variations in the histometric characteristics of the reproductive organs of pubertal West African dwarf bucks in their native tropical environment. Int. J. Morphol., 26(2):397-401, 2008.

Sod-Moriah, U. A.; Goldberg, G. M. \& Bedrak, E. Intrascrotal temperature, testicular histology and fertility of heart-acclimatized rats. J. Reprod. Fertil., 37(2):263-8, 1974.

Steel, R. G. D. \& Torrie, J. H. Principles and procedures of statistics, A Biometrical Approach. New York, Mc Graw - Hill. Book Co. Inc., 1980.

Sumberg, J. E. \& Cassaday, K. Sheep and goats in humid West Africa; proceedings of the Workshop on Small Ruminant Production Systems in the Humid Zone of West Africa, held in Ibadan, Nigeria. Addis Ababa, International Livestock Centre for Africa (ILCA), 1985.

Thimonier, J.; Terqui, M. \& Chemineau, P. Conduite de la reproduction de petits ruminants dans les differentes parties du monde. Vienna, Proc. Int. Atomic Energy Agency, 1986. pp.135-47.

Valez-Nauer, M.; Carew, B. A. R.; Mosi, A. K.; Opasina, B. A. \& Haywood, B. Productivity of The West African Dwarf goat at village level in South West Nigeria. Tucson, Arizona, Proc. $3^{\text {rd }}$. Int. Congr. On goat Production and disease, 1982. p.356.

Vandenberg, J. G. The penile smear: an index of sexual maturity in male golden hamsters. Biol. Reprod., 4(2):234-7, 1971.

Vandenmark, N. L. \& Free, M. J. Temperature effects. In: Johnson, A. D.; Gomes, W. R. \& Vandenmark, N. L. Eds. The Testis. New York, Academic Press, 1970. pp. 233-321.

Willis, B. M. Breeding policies in developing regions. In Dalton's introduction to practical animal breeding. $4^{\text {th }}$ ed. Blackwell Science, 2001. pp. 132-8.
Correspondence to:

Bitto, I. I.

Department of Animal Breeding and Physiology

University of Agriculture Makurdi

Makurdi

NIGERIA

Email: sibittos@yahoo.com

Received: 24-04-2007

Accepted: 12-02-2008 
